\title{
Aspect of Plato for Poets and Rhapsodists in the Dialogue of "Ion"
}

\author{
Marina Nasaina \\ National and Kapodistrian University of Athens, School of Philosophy
}

Received 23 February 2018 • Revised 20 May 2018 • 3 June 2018

\begin{abstract}
This particular paper refers to Plato's effort in the dialogue of "Ion" to prove to the homonymous rhapsodist that his skill in rhapsodic art - and especially in Homer - is not a result of professional art and science, but is due to divine power. Socrates in this Platonic dialogue develops the theory of divine inspiration. A divine impulse occupies the poets and then the rhapsodists to "emerge out of themselves" and to become the unconscious mouthpiece of a higher power that temporarily occupies them and inspires them to interpret their poems. In fact, Ion protested in a special way - and for the first time in Plato's work - the controversy of poetry and philosophy, aiming to make a meaningful reference to the superiority of the "crown of the sciences".
\end{abstract}

Keywords: Ion, Homer, poetry, divination, rhapsody, art, expert, divine, possessed.

What is Poetry? A conscious creation of the poet or divine inspiration? Starting with this question, Socrates in the Platonic dialogue of Ion develops the theory of divine inspiration (Bottner, 2000: 255), in order to prove to the homonymous rhapsodist (Kahn, 1996: 21) that his skill in rhapsodic art - and especially in Homer - is not the result of professional art and science (Dorter, 1973: 65; Ott, 1992: 27), but is due to divine power.

More specifically, Ion belongs to the chorus of Plato's early-defensive dialogues (Moore, 1974: 421) with a purely moral and pedagogical orientation. His author is deeply concerned with the predominant belief of his era that poetry and its actors constitute some of the educational and transformative axes of his society. Thus, despite the fact that the Plato shows to Ion Socrates a very critical one against the belief of the poets of his time that their works were not their own but the result of the divine destiny and mania from which they were dominated to become the carriers of the divine words to the people, nevertheless analyzes in detail the way in which the poet's creations are occupied by the "divine". He even speaks of his realization, referring to the decisive role that the rhapsodists play in the transmission of divine discourse to humans.

Irrespective of his original purpose, which is the undermining of the spiritual prestige of poetry, Plato does not develop a unanimous discourse on it, but - even through the possibilities given to him by the Socratic dialectical method - is in favor of philosophy. The poetic and, by extension, the rhapsody art obviously fall short of the top of the sciences, as the former prefer human "emotional excitement", while philosophy is aimed at the rational (McGregor, 1965: 15) and the "mental".

(C) Authors. Terms and conditions of Creative Commons Attribution 4.0 International (CC BY 4.0) apply. Correspondence: Marina Nasaina, Parodos Agiou Adrianou 89, 21100 Nauplio, GREECE. E-mail: mnassaina@gmail.com. 
The dialogue of Ion obviously carries a particularly dramatic or dramatized style, which is gradually exacerbated not only by the Platonic Socrates attempt to logically reason his interlocutor's thoughts, but mainly because of the endeavor of Ion to respond to this "challenge". Moreover, even in the case where Ion discusses a merciful subject for himself, that of Homeric poetry, he does not appear to respond adequately to the strictly rational schemes which have been "premeditated" or "spontaneously" by Socrates in the debate.

Thus, from the beginning of the dialogue, a necessary prerequisite for being considered as one virtuous rhapsodist is the understanding and correct interpretation of the poet's words in his audience (530c3-4) (Müller, 1998: 259), while the extensive use of definition referring to the way of acquiring the knowledge of understanding (530c1, 530c2-3, 530c5) of the virtuous rhapsodist promotes the correlation of virtue with knowledge and confirms the characteristics of the good professional.

Then the dialogue is structured into three dialectical, auditory speeches, each of which has a specific goal for the Athenian dialectic. Thus, in the first audit report (530b4-53od9), Socrates expresses his reservations as to whether and whether rhapsodists have embedded in the proper interpretation of poetic thoughts and, consequently, in their proper recitation.

Indeed, in this context, the Athenian dialectician accepts rhapsody art as an art - and indeed, with regard to Ion - as art, which focuses on his references to Homer's poetic compositions. But then Socrates will make his reservations about whether and whether the Ion is able to fully or adequately understand the content of the Homeric texts so as to escape a mere narrative reading. For this reason, he will invite Ion to his claims, that is to say, a practical demonstration of his ability to interpret Homer. Ion does not deny Socrates' incitement, but for the reinforcement of his allegations he puts forward an additional element in the debate: public opinion has recognized this status (Hening, 1964: 241), since he has honored him many times for his interpretations performance in Homer's poems (Murray, 2008: 102).

This first, then, auditing attempt by Socrates moves on his part within the framework of his obstetric-dialectic method. The philosopher from beginning "recommends" his interlocutor, but mainly incorporates the subject of discussion into a context-based framework.

In the second audit speech (530d10-536d8), the Athenian philosopher seems to lift, for the development of the debate, his above-mentioned urge to put Ion on the suffering of proving. He now selects a "targeted" question-response session to push his interlocutor into an attempt to deposit the epistemological "credentials" of the art he represents. In particular, he invites the rhapsodist to present the specific methodological principles, which are known to define or form a technical engagement. Thus, the philosopher asks Ion to clarify whether his work concerns only the poetic compositions of Homer or extend beyond them, that is, the poetry of Hesiod and Archilochus. In addition, Socrates invites Ion to state whether the rhapsodist himself is able to highlight Homer's qualitative differentiations from the other poets and to show to what extent his claim - that he has specialized in Homeric poetry - is after his new theoretical data that was introduced in their discussion. At this point, Socrates brings back the subject of knowledge, linking "virtue to knowledge" and adding the concept of power, shaping the form of virtueknowledge-ability. In other words, the Socratic control disputes the rhapsodic ability of Ion, which implies the correct interpretation of Homer's intellect, but also the whole of the values he conveys. This uncritical praise for the values of life and the educational significance of the way Homer proposes is at the heart of the philosopher. The morality of this praise is particularly risky because it promotes a passive way of thinking and cannot be proven by arguments. Someone is wise, because he is praised, not the other way round (Capuccino, 2011: 63).

Here, the dramatic but also the dialectical element seems to be at their peak as the Athenian philosopher introduces a remarkable note of Ion's claims; dealing with poetic texts is not meant to be specifics, since their subjects are generally common. Particularly it concerns issues of 
both private and public life of individuals. But as long as Socrates's remark looks like "restrictive" and "appealing" with the evolution of dialogue, it leaves room for it to be rescinded. However, such an attempt on the part of Ion requires a strong argumentation, so at least he "provokes" his rational and critical capacity.

Ion does not understand the new ways of developing his reasoning, which Socrates "generously" concedes to him. Ion agrees with the view of the poet's common themes, nevertheless he states that the differences that arise between them are related to the specific stylistic choices of each poet.

The philosopher, as he discovers that his interlocutor does not understand that the matter requires more of a thoughtful negotiation than a documentary - dogmatic type either from the subject or the environment of the common "customary" acceptance - undertakes the task of putting himself the rational methodological components of his problematic subject. He selects, therefore, to incorporate rhapsodic art into the environment of the original, Socratic sciences, such as those in mathematics and medicine. The philosopher's intention is to demonstrate that the art of rhapsody lacks any scientific validity. Besides, according to Friedländer (1964: 131) and Verdenius (1943: 262), it is argued that the Platonic attack on their rhapsodists and educational claims was one of the intentions of the dialogue, while Saunders adds that disclaiming the possession of art by rhapsodists and poets is part of his belief that morality is an art that is acquired through dialectics. (Saunders, 1987: 41) Finally, Kahn emphasizes that poetry - and especially Homeric - is not the object of Platonic critique as a form of art; on the contrary, it is criticized for its educational purpose and the moral and intellectual influence it exercises (Kahn, 1996: 373).

However, if Ion claims a similar recognition to that of the mathematician and physician, he must admit that he is capable of judging and evaluating adequately anyone involved in epic poetry. However, Ion insists on his original position, that is, he has thoroughly dealt with something exclusively in Homer's poetry. So, for Socrates, he is deprived basic knowledge of the art he represents, so it is not feasible, without them, to have made specialized.

Nevertheless, Socrates seems to control his findings in such a way that he avoids, at least, the disfavor of his interlocutor. So, now, he will note that Ion's technical skills are moving beyond the spectrum of science and, rather, approaching that of the divine contribution to their unfolding. At this point, Plato exposes the theory of divine inspiration and the role that, according to the perception of the time, Muse played. Muse played the role of mediator between gods and poets, the "interpreter", who undertook to transform the divine will into poetic inspiration, and she, in turn, gave birth to the poetic/epic creation. The divine inspiration that through Muse forced the poetic thoughts of the creators removed the logic of the poets, who, being frenetic and without human conscience, imprinted with their creation the god. Muse, of course, was herself a divine entity, and Plato says that many times she was the divine cause of inspiration. She did not just play the role of the interpreter and mediator, but she kept the poets and through their works she gave her speech to people.

According to the above theory, poets are the first stage of divine power transmission (Rijksbaron, 2007: 9), who are unable to compose poems with their logic (Harris, 2004: 189). They are only mouthpieces of divine speech (Gould, 1992: 13). Thus, the ancient poet produces effectively poems, precisely because at the time of his composition he is possessed of a divine power. In other words, the man he produces is not man but God. The poets themselves, moreover, accept the subscription assistance of the Muses, which help the initiator enter into an incompetent state in order to fully understand the field of their interests. This inherent situation of poetic creation is the main cause of the separation of all poetry into the various poetic categories (dithyramb (Lesky, 1963: 328), elegía (Lidell-Scott, 1997: 615) epic poetry, (Lesky, 2006: 169) iamb, (Lesky, 2006: 300)). According to Wood, Socrates distinguishes two kinds of human thought: the use of pre-existing knowledge through the adoption of rules and principles that are 
already known and authenticity and modernity. For man there is only production through technical knowledge (Wood, 1997: 191).

The second stage of the divine power transmission is the rhapsodists, who interpret the poets thus become interpreters of God's interpreters. The way the poet's words are transferred to the viewer are only realized when they leave their logic and their soul describes the events just as they experienced them. That is, rhapsodist was the last link of the chain "God-Muse-poetrhapsodist", before the divine word of the poet's divine inspiration reaches the earth. Ion agrees with Socrates to tell him that he approaches the "divine mystery" of Homer, both experiential and emotionally, so that he can carry it without "crushing" his viewers, who are the final stage of divine transmission (Wyller, 1958: 26). Of course, he is quick to point out that such an activity would be unsuccessful if he had not become cognitive in the poetic texts.

The specific, therefore, appeals of Socrates in his second attempt attempts to show that: (a) any enthusiasm for something does not in itself constitute a technical commitment; (b) the interpretation of poetic texts is not based on methodological "constants", so it does not cover the epistemological criteria of an art or science; (c) even poetry - rather, rhapsodic - is not determined by the rational criteria of the arts, but according to the emotional or psychological excitement caused by "divine fury".

The third audit speech (536d9-541e1) summarizes through many exemplary references what has been said before, that rhapsodic, as an interpretation of poetry, abstains from the firm functioning of the arts, which is no more than the correct representation and imprinting of reality. Even if we accept, according to Socrates, that each poet attributes, as far as possible, aspects of reality, then the rhapsodist, which interprets the poet, is far from a straight and direct contact with the objective space-time. More so, when the poet, inspired by Muse, "perceives" the reality, he approaches the real exogenous and highly emotional.

In particular, in this third part of the dialogue, Socrates will again invite Ion to prove his allegations. He even asks Ion to what extent he is able to make the successful expressive depiction of all Homer's specific descriptions of other technical activities. If, at this point, Ion also claims that he has such descriptive or interpretative skills, would he not, according to the Athenian dialectic, also possess the proportions of the art of poetry?

Socrates, as Ion maintains his allegations, will argue that any technical occupation strictly and specifically cure a cognitive field of the scientist and concerns only the area of human activity, which is denoted by its naming. Therefore, even rhapsody, which focuses on a limited space of worldly occupations, cannot be identified or resemble other technical activity. So that one can properly judge the individual arts that are mentioned in Homer requires the knowledge of the individual arts (Rijksbaron, 2007: 195). In the case of Homeric poetry, which includes and portrays many technical activities in its references, a "multifaceted" personality with a wider knowledge of poetry but also of the other arts of Homer.

At the end of the dialogue, Ion fails to capture the catalytic power of the concept of knowledge, which differentiates the arts. The Socratic method triumphs. The equation of virtuous rhapsodist with virtuous general demonstrates the injustice of Ion, since his promise that his Homeric interpretation is a derivative of his art and science, as well as his promise that he is absolute knowledgeable of Homer was not followed by analogy demonstrating his knowledge. Ion's technical skills do not constitute or have no gnostic texture, since they do not arise as a cognitive product, but exist as a derivative of divine inspiration from the Muses (Duncan, 1945: 481; Woolf, 1997: 192). However, Socrates does not hesitate to acknowledge Ion's divine influences, a confession, which is not only "recorded" as acceptance of Ion's abilities, but not even more of poetry. His interlocutor, in fact, did not succeed in treating him to the contrary. 
The result of the dialogue is as follows: rhapsodist Ion is a divine (Verdenius, 1983: 42-43; Ott, 1992: 33) and not a technical interpreter of Homer. That is, the virtue of rhapsodist is the result of divine occupation, since according to Socrates rhapsodic and poetic art are not human creations, as they are not arts with a particular subject (Henning, 1964: 244). The virtue of rhapsody and poetic art cannot be the right criterion of productivity and efficiency for the human level as it has divine roots (Weineck, 1998: 26). On the contrary, in the context of human creation, knowledge alone is the right criterion which can produce human creations in the right way. So, in this way he rejects poetic and rhapsodic creation from human activities, for as divine creations refer to out of human situations.

In our view, however - and given that the discussion seems to end in its starting point - it seems that in its logical paths it overlapped, in general, the initial ambitions of the two interlocutors; i.e. on the one hand, Socrates' explicit conviction that philosophy, as the crown of science, also sets the conditions for the incorporation of a human skill in their region and, on the other hand, Ion's implicit mood to not affect the credibility of the poets over the public opinion.

\section{Acknowledgements}

This research did not receive any specific grant from funding agencies in the public commercial, or not-for-profit sectors.

The author declares no competing interests.

\section{References}

Bloom, A. (1970). An Interpretation of Plato's Ion, Interpretation I.

Büttner, S. (2000). Die Literaturtheorie bei Platon und ihre anthropologische Begrundung.

Capuccino, C. (2011). Plato's Ion and the ethics of praise. In: P. Destrée \& F. G. Herrmann (Eds.), Plato and the poets. Leiden - Boston, Brill.

Dorter, K. (1973). The Ion. Plato's characterization of art. The Journal of Aesthetics and Art Criticism, 32, 1.

Duncan, T. S. (1945). Plato and poetry, Classical Journal, 40.

Friedländer, P. (1964). Plato. The dialogues. Vol. II. London.

Gould, J. (1992). Plato and the performance. In: A. Barker \& M. Warner (Eds.), The language of the cave. Edmonton.

Green, R. K. (2001). Democratic virtue in the trial and death of Socrates. New York.

Harris, J. P. (2004). Art and divine inspiration in Plato's Ion. In: R. B. Egan \& M. Joyal (Eds.), Daimonopylai: Essays in classics and the classical tradition presented to Edmund G. Berry. Manitoba.

Henning, R. B. (1964). A performing musician looks at the "Ion". Classical Journal, 59.

Kahn, C. (1996). Plato's Ion and the problem of techne. In: R.M. Rosen \& J. Farrell (Eds.), Nomodeiktes. Greek studies in honor of Martin. Ostwald: Ann Arbor.

Liddell, H., \& Scott, R. (1997). Mega dictionary of Greek language, Greek translation: Moschou, Edition I. Athens: Sideris. 
Lesky, (1963). History of old Greek arts (Greek translation of A. Tsopanakis). Thessaloniki: University of Thessaloniki.

Lesky, (2006). History of old Greek literature (Greek translation A. G. Tsopanakis). Athens: Kiriakidis.

McGregor, J. M. (1965). Plato. Ion. Cambridge.

Moore, D. (1973). Limitation and design in Plato's Ion, Pacific Coast Philology, 8.

Müller, C. W. (1998). Die Dichter und Ihre Interpreten: Über die Zirkularität der Exegese von Dichtung Im Platonischen Ion. In: Rheinisches Museum 141 (259-285).

Murray, P. (2008). Plato on poetry, University Press, Cambridge.

Ott, S. D. (1992). A commentary on Plato's Ion. Diss. Brown University, Rhode Island.

Rijksbaron, (2007). Plato: Ion. Or: On the Iliad. Brill, Leiden (kritische Edition mit Einführung und Kommentar).

Saunders, T. J. (Ed.) (1987). Plato. Early Socratic dialogues. London.

Verdenius, W. J. (1943), L' Ion de Platon. Mnemosyne, n.s. 11.

Verdenius , W. J. (1983). The principles of Greek literary criticism. Mnemosyne, NS 4.36. 